\title{
3 Research Square

\section{The genus Dermoloma is more diverse than expected and forms a monophyletic lineage in the Tricholomataceae}

\section{Marisol Sánchez-García}

Swedish University of Agricultural Sciences: Sveriges lantbruksuniversitet

Katarína Adamčíková

Slovak Academy of Sciences: Slovenska akademia vied

\section{Pierre-Arthur Moreau}

Université de Lille

Alfredo Vizzini

University of Torino

\section{Soňa Jančovičová}

Comenius University in Bratislava: Univerzita Komenskeho v Bratislave

\section{Munazza Kiran}

University of the Punjab

\section{Miroslav Caboň}

Slovak Academy of Sciences: Slovenska akademia vied

\section{Patrick Brandon Matheny}

University of Tennessee

Slavomír Adamčík ( $\nabla$ slavomir.adamcik@savba.sk)

Slovak Academy of Sciences https://orcid.org/0000-0003-2156-5767

\section{Research}

Keywords: Agaricales, infrageneric classification, systematics, taxonomy, types, CHEGD fungi

Posted Date: October 2nd, 2020

DOI: https://doi.org/10.21203/rs.3.rs-84952/v1

License: (c) (i) This work is licensed under a Creative Commons Attribution 4.0 International License. Read Full License 


\section{Abstract}

We present the first phylogenetic evaluation of the genus Dermoloma, which is resolved as monophyletic and closely related to Pseudotricholoma, a poorly-known Dermoloma -like lineage within the family Tricholomataceae. The position of Dermoloma is confirmed by the placement of the type species, D. cuneifolium , represented by multiple samples including the neotype. Based on our phylogenetic analyses, we recognised 25 European operational taxonomic units (OTUs), but could only assign species names to ten of them based on ex-type sequences. Furthermore, only five additional published Dermoloma names of uncertain status are available for the remaining 16 potential European species, thus demonstrating an unexpected amount of taxonomic diversity. Samples from Europe and North America seem to be endemic on a continental scale. North American samples formed six unique OTUs, but only one could be reliably named, D. hymenocephalum. Dermoloma is morphologically defined by basidiomata with brown, grey and white colours with a farinaceous odour and a pluristratous hymeniderm type of pileipellis. Our phylogenetic analyses support the subdivision of the genus into two subgenera and four sections, species with inamyloid basidiospores are placed in subg. Dermoloma and those with amyloid basidiospores in subg. Amylospora . Both subgenera are further divided in two sections. The analysis of spore morphology shows that sect. Conica of subg. Dermoloma and sect. Nigrescentia of subg. Amylospora have a very distinctive spore shape. Sect. Atrobrunnea of subg. Amylospora showed relatively high variability of spores among species, but spores of sect. Dermoloma were similar and not useful for species discrimination.

\section{Introduction}

The genus Dermoloma (J. Lange) Singer ex Herink is a poorly known group of agarics defined by small to medium-sized basidiomata of collybioid to tricholomatoid habit with dull grey, brownish, or white colorations; sinuate to adnate-decurrent lamellae; farinaceous smell (or taste); smooth, hyaline, amyloid or inamyloid basidiospores and a pileipellis of a pluristratuous (multi-layered) hymeniderm type (Arnolds 1992; Singer 1975, 1986). Thirty-nine unique names at species and lower rank have been published or combined in the genus (http://www.mycobank.org, http://www.indexfungorum.org). Among them, 25 were published from Europe, six from the Americas and eight from other continents. Among European names, four are invalid or illegitimate and three are infraspecific taxa. This means that 18 valid species names are published from Europe (Table 1).

The number of accepted species has varied over the years in Europe. Bon $(1986,1998)$ accepted eight species but only three were adopted by Arnolds $(1992,1993)$, who later added one more European species (Arnolds 2002). It is not clear if Contu et al. (2008) accepted all previously described European species as separate taxa, but they considered that the diversity of European Dermoloma was higher and described four new species, one of which was not validly published. Only three species are included in a recent key of Nordic mycobiota (Vesterholt 2008, 2012). European species are mostly found in grassland ecosystems and are part of a group of fungi with special conservation interest that has been referred to as CHEGD (acronym of taxon names with the last letter referring to Dermoloma) (Griffith et al. 2013). The 
diversity of the genus in North America has not been explored and only a single species, $D$. hymenocephalum (A.H. Smith) Singer has been described from the USA (Singer 1962).

Dermoloma is classified in the family Tricholomataceae R. Heim ex Pouzar (www.mycobank.org) based on morphological characters (Singer 1975, 1986). Bon (1979) proposed an alternative morphology-based placement based on the pileipellis structure in the family Dermolomataceae (Bon) Bon, but this was not generally accepted. The first phylogenetic study that included a member of the genus placed $D$. inconspicuum Dennis close to the genus Lepiota (Pers.) Gray in the family Agaricaceae Chevall (Kropp 2008). Sánchez-García \& Matheny (2016) recently placed five Dermoloma samples in the family Tricholomataceae, within a clade sister to the genus Tricholoma (Fr.) Staude. In their phylogenetic tree, the monophyletic genus Pseudotricholoma (Singer) Sánchez-García \& Matheny is nested within Dermoloma, making the latter paraphyletic. Dermoloma species are traditionally grouped in two sections, $D$. sect. Dermoloma with inamyloid basidiospores and $D$. sect. Atrobrunnea with amyloid basidiospores (Contu et al. 2008).

Different opinions about classification at family rank suggest that the morphological concept of the genus Dermoloma might correspond to several unrelated phylogenetic lineages. Variable species concepts in the European literature focused on spore characters, in combination with additional field characters, suggest that species taxonomy needs extensive revision. Here, we produce the first phylogenetic study of the genus. Our aims are to (i) verify if morphological circumscription of the genus corresponds to a monophyletic group, (ii) define the phylogenetic placement of the genus, including morphological and phylogenetic limits, (iii) estimate if species diversity in Europe and North America correspond to current taxonomic opinions, (iv) assign species names to clades fixed by sequencing type collections and (v) specify phylogenetic signal and taxonomic relevance of spore characters.

\section{Material And Methods}

\section{Taxon sampling}

The study combined type material and other samples collected or gathered by the authors. We were able to borrow 20 of 23 existing Dermoloma types from Europe and North America (Table 2). Recent material consisted of additional 90 specimens collected from Estonia (1 collection), France (14), Italy (2), Romania (8), Slovakia (26), Switzerland (1), United Kingdom (33) and the USA (2), and 13 borrowed herbarium specimens from Italy (8), Sweden (4) and the USA (8). Dermoloma samples collected by the authors of this study were identified based on agaricoid basidiomata of grey, brown and white colour, hymeniderm pileipellis and usually conspicuous farinaceous odour (Arnolds 1992). 
Table 2

List of European and North American type and authentic herbarium material and sequencing results. HT

- holotype, NT - neotype, AM - authentic material, GB - will be replaced by a Genbank number.

\begin{tabular}{|c|c|c|c|c|}
\hline species & collection details & Herbarium & $\begin{array}{l}\text { type } \\
\text { status }\end{array}$ & $\begin{array}{l}\text { sequencing } \\
\text { outputs }\end{array}$ \\
\hline D. alexandri Cons. & $\begin{array}{l}\text { ITALY. Mesole (FE), Boscone della } \\
\text { Mesola, G. Consiglio, M. Panchetti, R. } \\
\text { Bolletta \& C. Orlandini, 12. Sep } 2004\end{array}$ & $\begin{array}{l}\text { herbarium of } \\
\text { G. Consiglio } \\
\text { (GC04317) }\end{array}$ & $\mathrm{HT}$ & GB \\
\hline $\begin{array}{l}\text { D. atrocinereum } \\
\text { (Pers.) P.D. Orton }\end{array}$ & $\begin{array}{l}\text { ITALY. Villeta Barrea (AQ), Abruzzo, } \\
\text { M. Contu et al., 19. Sep } 2003\end{array}$ & $\begin{array}{l}\text { AQUI (Contu } \\
\text { 19.IX.2003) }\end{array}$ & NT & GB \\
\hline D. bellerianum Bon & FRANCE. Beller, 30. Sep 1972 & $\begin{array}{l}\text { LIP (Bon } \\
912)\end{array}$ & HT & not located \\
\hline $\begin{array}{l}\text { D. coryleti Singer \& } \\
\text { Clémençon }\end{array}$ & $\begin{array}{l}\text { CZECHIA. Kroměříš, R. Singer, } 30 . \\
\text { Sep } 1970\end{array}$ & $\begin{array}{l}\text { F (R. Singer } \\
\text { C-5230) }\end{array}$ & HT & $\begin{array}{l}\text { not } \\
\text { accessed }\end{array}$ \\
\hline $\begin{array}{l}\text { D. cuneifolium (Fr.: } \\
\text { Fr.) Bon }\end{array}$ & $\begin{array}{l}\text { SWEDEN. Småland, Femsjö, } \\
\text { 'Avaberget', S. Lundell \& G. Haglund, } \\
\text { 19. Sep } 1948\end{array}$ & $\begin{array}{l}\text { UPS F- } \\
631065\end{array}$ & NT & GB \\
\hline $\begin{array}{l}\text { D. cuneifolium var. } \\
\text { punctipes Arnolds }\end{array}$ & $\begin{array}{l}\text { NETHERLANDS. prov. Limburg, } \\
\text { Wijlre, 'Wrakelberg', E. Arnolds, } 22 . \\
\text { Oct } 1984\end{array}$ & L 0821553 & HT & GB \\
\hline $\begin{array}{l}\text { D. emiliae-dlouhyi } \\
\text { Svrček }\end{array}$ & $\begin{array}{l}\text { CZECHIA. Brdské hřebeny Mts., } \\
\text { Vižina, M. Svrček, 20. Sep } 1965\end{array}$ & PR 610931 & $\mathrm{HT}$ & failed \\
\hline $\begin{array}{l}\text { D. fuscobrunneum } \\
\text { P.D. Orton }\end{array}$ & $\begin{array}{l}\text { UK. Somerset, Bickham Wood, } \\
\text { Crawley, P.D. Orton, 24. Oct } 1975\end{array}$ & E 16876 & $\mathrm{HT}$ & failed \\
\hline $\begin{array}{l}\text { D. hybridum } \\
\text { (Kühner) Bon }\end{array}$ & $\begin{array}{l}\text { FRANCE. bois d'Avoudrey (près } \\
\text { Besançon), R. Kühner, } 16 \text {. Oct } 1946\end{array}$ & G 126676 & HT & failed \\
\hline $\begin{array}{l}\text { D. hygrophorus } \\
\text { Joss. }\end{array}$ & $\begin{array}{l}\text { FRANCE. Ain, Quincieux, Lacombe \& } \\
\text { Josserand, 14. Aug } 1956\end{array}$ & G 260855 & HT & $\begin{array}{l}\text { GB, partial } \\
\text { ITS } \\
\text { sequence }\end{array}$ \\
\hline $\begin{array}{l}\text { D. } \\
\text { hymenocephalum } \\
\text { (A.H.Sm.) Singer }\end{array}$ & $\begin{array}{l}\text { USA. Michigan, Dexter, Silver lake, } \\
\text { A.H. Smith, 23. Sep } 1938\end{array}$ & MICH 10228 & $\mathrm{HT}$ & $\begin{array}{l}\text { GB, partial } \\
\text { ITS } \\
\text { sequence }\end{array}$ \\
\hline $\begin{array}{l}\text { D. intermedium } \\
\text { Bon }\end{array}$ & $\begin{array}{l}\text { FRANCE. Somme, Warlus, towards } \\
\text { Airaines, M. Bon, Oct. } 1967\end{array}$ & $\begin{array}{l}\text { LIP (Bon } \\
71081)\end{array}$ & $\mathrm{HT}$ & failed \\
\hline $\begin{array}{l}\text { D. intermedium var. } \\
\text { coniferarum Bon }\end{array}$ & $\begin{array}{l}\text { FRANCE. Argol, Mornard, 28. Oct } \\
1982\end{array}$ & $\begin{array}{l}\text { LIP (Bon } \\
8116)\end{array}$ & HT & $\begin{array}{l}\text { GB, not } \\
\text { Dermoloma }\end{array}$ \\
\hline $\begin{array}{l}\text { D. josserandii } \\
\text { Dennis \& P.D. Orton }\end{array}$ & $\begin{array}{l}\text { UK. South Somerset, Spaxton, } \\
\text { Hawkridge, E. Marrigae, 15. Sep } 1958\end{array}$ & $K(M) 37580$ & HT & failed \\
\hline $\begin{array}{l}\text { D. Iongibasidiatum } \\
\text { Cons., Contu \& } \\
\text { Setti }\end{array}$ & $\begin{array}{l}\text { ITALY. Pergine (TN), Susà, G. } \\
\text { Consiglio, G. Marasca et B. Oss-Emer, } \\
\text { 30. Nov 1993, }\end{array}$ & $\begin{array}{l}\text { herbarium of } \\
\text { G. Consiglio } \\
\text { (GC93318) }\end{array}$ & $\mathrm{HT}$ & failed \\
\hline
\end{tabular}




\begin{tabular}{|c|c|c|c|c|}
\hline species & collection details & Herbarium & $\begin{array}{l}\text { type } \\
\text { status }\end{array}$ & $\begin{array}{l}\text { sequencing } \\
\text { outputs }\end{array}$ \\
\hline $\begin{array}{l}\text { D. magicum } \\
\text { Arnolds }\end{array}$ & $\begin{array}{l}\text { NETHERLANDS. Limburg, Epen, } \\
\text { Cotessen, E. Arnolds, 21. Oct } 1995\end{array}$ & $\begin{array}{l}\mathrm{L}(\text { Arnolds } \\
6701)\end{array}$ & HT & not located \\
\hline $\begin{array}{l}\text { D. murinellum E. } \\
\text { Horak }\end{array}$ & $\begin{array}{l}\text { SWITZERLAND. Graubünden, N des } \\
\text { Albulpasses (Terrassas), E. Horak, } \\
\text { 30. Aug } 1982\end{array}$ & $\begin{array}{l}\text { ZT Myc } \\
42786 \\
\text { (Horak } \\
\text { ZT1573) }\end{array}$ & $\mathrm{HT}$ & failed \\
\hline $\begin{array}{l}\text { D. phaeopodium } \\
\text { P.D. Orton }\end{array}$ & $\begin{array}{l}\text { UK. Devon, Membury, P.D. Orton, } 28 . \\
\text { Oct } 1977\end{array}$ & E 16877 & HT & GB \\
\hline $\begin{array}{l}\text { D. pragense } \\
\text { Kubička }\end{array}$ & $\begin{array}{l}\text { CZECHIA. Praha, "Kinského sady“, E. } \\
\text { Wichanský 22. Jun } 1965\end{array}$ & PR 611173 & HT & failed \\
\hline $\begin{array}{l}\text { D. pragense f. } \\
\text { obscurum Cons. \& } \\
\text { Contu }\end{array}$ & $\begin{array}{l}\text { ITALY. Monte Grino, near Piobbico } \\
\text { (PU), G. Consiglio \& M. Maletti, } 22 . \\
\text { Oct } 2006\end{array}$ & $\begin{array}{l}\text { herbarium of } \\
\text { G. Consiglio } \\
\text { (GC06186) }\end{array}$ & HT & GB \\
\hline $\begin{array}{l}\text { D. } \\
\text { pseudocuneifolium } \\
\text { Herink ex Bon }\end{array}$ & $\begin{array}{l}\text { FRANCE. near Saint-Valery-sur- } \\
\text { Somme, Oct } 1968\end{array}$ & $\begin{array}{l}\text { LIP (Bon } \\
81006)\end{array}$ & HT & failed \\
\hline D. pusillum Contu & $\begin{array}{l}\text { ITALY. Sardinia, Olbia (OT), } \\
\text { Pittolongu, M. Contu, 30. Dec } 2006\end{array}$ & $\begin{array}{l}\text { AQUI (Contu } \\
\text { 30.XII.2006) }\end{array}$ & HT & GB \\
\hline $\begin{array}{l}\text { D. simulatum } \\
\text { Cons., Contu \& } \\
\text { Setti, nom. inval. }\end{array}$ & $\begin{array}{l}\text { ITALY. Trento-Alto Adige, Susà (TN), } \\
\text { G. Consiglio, G. Marasca \& B. Oss- } \\
\text { Emer, 30. Oct } 1993\end{array}$ & $\begin{array}{l}\text { herbarium of } \\
\text { G. Consiglio } \\
\text { (GC02284) }\end{array}$ & AM & failed \\
\hline
\end{tabular}

\section{DNA extractions and sequencing}

A small piece of dried material (10-30 mg) was removed and ground in a $1.5 \mathrm{ml}$ tube with sterilized sand, liquid nitrogen and a micropestle. Genomic DNA was extracted using the E.Z.N.A. Fungal DNA Mini Kit (Omega Bio-Tek Inc., Norcross, GA, USA), and the E.Z.N.A. HP Fungal DNA kit (Omega Bio-Tek) following the manufacturer's instructions. Genomic DNA was serially diluted into two 1:10 dilutions with sterile water. The following loci were targeted: (i) the internal transcribed spacer regions of nuclear ribosomal DNA (nrITS), (ii) nuclear ribosomal large subunit (nrLSU), (iii) the first largest subunit of RNA polymerase II (rpb1) and (iv) the most variable region between domains six and seven of the nuclear gene encoding the second largest subunit of RNA polymerase II ( $r p b 2)$. Amplification of DNA was performed using a PCR mix consisting of approximately $2 \mathrm{ng} / \mu \mathrm{l}$ of template DNA, forward and reverse primers $(10 \mathrm{pmol} / \mu \mathrm{l}), 5 \times$ HOT FIREPol $\circledast$ Blend Master Mix (Solis BioDyne, Tartu, Estonia) and molecular grade water added up to $20 \mu \mathrm{l}$, or using a mixture of $5 \times$ buffer, GoTaq, and dNTPs supplied by Invitrogen Corp. (Carslbad, CA, USA). All PCRs started with an initial denaturation step at $95^{\circ} \mathrm{C}$ for $15 \mathrm{~min}$.

The nrITS was amplified with the primers ITS1F-ITS4 (Gardes \& Bruns 1993, White et al. 1990). Reaction conditions consisted of denaturation at $95^{\circ} \mathrm{C}$ for $35 \mathrm{~s}$, annealing at $55^{\circ} \mathrm{C}$ for $55 \mathrm{~s}$ and elongation at $72{ }^{\circ} \mathrm{C}$ for $45 \mathrm{~s}$. Then followed by 13 cycles of denaturation at $95^{\circ} \mathrm{C}$ for $35 \mathrm{~s}$, annealing at $55^{\circ} \mathrm{C}$ for $55 \mathrm{~s}$ and 
elongation at $72{ }^{\circ} \mathrm{C}$ for $2 \mathrm{~min}$ and the last 9 cycles with the same conditions for denaturation and annealing, with a longer elongation of $3 \mathrm{~min}$. A final extension was carried out at $72{ }^{\circ} \mathrm{C}$ for $10 \mathrm{~min}$. The nrLSU was amplified using the primer pairs LROR/LR16, LROR/LR5 or LROR/LR7 (Vilgalys \& Hester 1990, https://sites.duke.edu/vilgalyslab/rdna_primers_for_fungi/). The PCR conditions were as follows: $1 \mathrm{~min}$ at $95^{\circ} \mathrm{C}, 1 \mathrm{~min}$ at $50^{\circ} \mathrm{C}, 1 \mathrm{~min}$ at $72{ }^{\circ} \mathrm{C}$, repeated 35 times and a final extension step for $10 \mathrm{~min}$ at $72{ }^{\circ} \mathrm{C}$. The primers bRPB2-6F and bRPB2-7.1R (Matheny 2005) were used to amplify the rpb2 region. PCR conditions were as follows: $1 \mathrm{~min}$ at $95^{\circ} \mathrm{C}, 1 \mathrm{~min}$ at $58^{\circ} \mathrm{C}$, an increase of $1^{\circ} \mathrm{C}$ per $5 \sec$ to $72{ }^{\circ} \mathrm{C}, 1 \mathrm{~min}$ at $72{ }^{\circ} \mathrm{C}$, repeated 35 times, finalized by $10 \mathrm{~min}$ at $72{ }^{\circ} \mathrm{C}$. The RPB 1 region was amplified using the primers gRPB1-A for and fRPB1-C rev (Matheny et al. 2002) under the following PCR conditions $1 \mathrm{~min}$ at $95^{\circ} \mathrm{C}$, $1 \mathrm{~min} 30 \mathrm{~s}$ at $55^{\circ} \mathrm{C}$, an increase of $1^{\circ} \mathrm{C}$ every $5 \mathrm{sec}$ to $72{ }^{\circ} \mathrm{C}, 2$ min at $72{ }^{\circ} \mathrm{C}$, repeated 35 times, finalized by $10 \mathrm{~min}$ at $72^{\circ} \mathrm{C}$.

The targeted fragments were purified using a PCR Purification Kit (Qiagen, Hilden, Germany). Sequence reactions were performed with BigDye Terminator 3.1 (Applied Biosystems, Foster City, California, U.S.A) and purified using Sephadex G-50 columns (General Electric Healthcare, Piscataway, New Jersey, U.S.A). Sequencing was performed at the University of Tennessee Genomics Core and the SEQme sequencing Company (Dobříš, Czech Republic).

\section{Sequence editing and phylogenetic analyses}

Sequence files were edited in Geneious version R10 (Kearse et al. 2012). Intra-individual polymorphic sites having more than one signal were marked with NC-IUPAC ambiguity codes. For phylogenetic placement of the genus Dermoloma within the family Tricholomataceae, we used Dermoloma samples represented by sequences of at least two DNA loci supplemented with sequences of the genera Albomagister, Corneriella, Dennisiomyces, Leucopaxillus, Porpoloma, Pseudobaeospora, Pseudotricholoma, Tricholoma and an undetermined genus published by Sánchez-García et al. (2014) and Sánchez-Gárcia \& Matheny (2016). Pseudoomphalina kalchbrenneri LAS06/037 was used as the outgroup. We performed independent analysis of the genus Dermoloma adding also ITS sequences retrieved from material of low quality DNA including the types. The clade that was inferred as sister to Dermoloma in the Tricholomataceae analysis was used as the outgroup in the Dermoloma tree. This second analysis allowed us to identify species clades based on the placement of the type specimens and to estimate more accurately the diversity of the genus. The datasets were aligned in MAFFT 7 using the EINS-i strategy (Katoh \& Standley 2013) and manually improved in Geneious R10 (Kearse et al. 2012). Divergent and ambiguously aligned positions of ITS and LSU were removed with Gblocks (Castresana 2000 ) using the least stringent parameters. Intronic positions of $r p b 1$ and $r p b 2$ were manually removed. Final alignment files are uploaded to TreeBase (\# XXXXX).

The final multi-loci datasets were analysed using the Cipres Science Gateway (Miller et al. 2010) with two different methods: Bayesian inference (BI) and maximum likelihood (ML). For the $\mathrm{ML}$ analyses, the concatenated alignments were uploaded as fasta files and analysed using RAXML-HPC2 on XSEDE (8.2.12) (Stamatakis 2014) as a partitioned dataset under the GTR + GAMMA model with 1000 bootstrap iterations. For the BI analysis, the dataset was divided into ten partitions: ITS1, 5.8S, ITS2, LSU, and the 
1st, 2nd and 3rd codon positions of $r p b 1$ and $r p b 2$. The best substitution model for each partition was computed jointly in Partitionfinder 1.1.1 (Lanfear et al. 2012). The aligned fasta datasets were converted to nexus format using Mesquite 3.61 (Madison and Madison 2019) and further analysed using MrBayes 3.2.6. (Ronquist et al. 2012) on XSEDE. Bayesian runs were computed independently twice with four MCMC chains for 10 million generations until the standard deviation of split frequencies fell below the 0.01 threshold. The convergence of runs was visually assessed using the trace function in Tracer 1.6 (Rambaut et al. 2013). The trees were visualized and annotated with TreeGraph 2 (Stöver and Müller 2010), and graphically improved in CorelDRAW X5 (Ottawa, Canada).

\section{Morphological observations}

Based on field observations and photographs, we assigned basic general basidiomata morphology to the resulting clades. Since previous works have emphasized the importance of spore characters in this genus, we measured spore dimensions and amyloid reaction of five individuals (when available) per each operational taxonomic unit (OTU) defined in our Dermoloma phylogeny. Spores were observed under Olympus BX43 microscope by Promicra 3-3CP camera. Spores were measured 20 or 30 times per sample using QuickPHOTO MICRO 3.2 software. Spore amyloidity was assessed in Melzer's reagent. Spore statistics were calculated with MS Excel and plotted using CorelDRAW X5 software.

\section{Results}

\section{Phylogeny}

In total, we analysed 119 Dermoloma samples. In our multi-loci analysis, they are represented each by ITS sequences (119 in total), and by 55 LSU sequences, 51 rpb2 sequences and 17 rpb1 sequences (Supplementary Table S1). The resulting alignment for the Tricholomataceae dataset resulted in 453 nrITS positions, $882 \mathrm{nrLSU}$ positions, $449 \mathrm{rpb} 1$ positions and $699 \mathrm{rpb} 2$ positions. The Dermoloma dataset alignment consisted of $568 \mathrm{nrlTS}$ positions, $805 \mathrm{nrLSU}$ positions, and identical rpb1 and rpb2 positions number.

Almost all of the sequenced Dermoloma samples were placed in a large and well-supported monophyletic group within the family Tricholomataceae. This core Dermoloma clade is sister to a clade containing the genus Pseudotricholoma (Singer) Sánchez-García \& and Matheny, and a clade we referred to as $\square$ Dermoloma-like $\square$ (Fig. 1). There is a distinct clustering within the genus that corresponds to two clades classified at subgeneric rank into the subgenus Dermoloma and the subgenus Amylospora subg. nov. (for formal designation of the new name see below). Subgenus Dermoloma was identified by placement of the neotype sequence of the type species D. cuneifolium (Fr.) Singer ex Bon. Each subgenus consisted of one large core clade with tens of collections and a small residual clade with few samples. Both small residual clades were strongly supported on a long branch and therefore we propose further subdivision of subgenera into sections. Sections Dermoloma and Conica sect. nov. are placed in the subg. Dermoloma and sections Atrobrunnea Contu and Nigrescentia sect. nov. in the subgenus Amylospora. Two 
sequences putatively identified as Dermoloma ( $₫$ Dermoloma-like $\triangle$ clade in Fig. 1 ) may represent an undescribed genus sister to Pseudotricholoma.

We recognised in total 31 OTUs within the genus Dermoloma that may represent potential species (Fig. 2). Fifteen OTUs are represented by a single collection. Section Dermoloma is represented by 11 OTUs, section Conica by two, section Atrobrunnea by 16 and section Nigrescenti by a single species $D$. magicum Arnolds. All OTUs strictly consisted of material from a single continent, either Europe or North America. Five OTUs of the section Atrobrunnea were North American and a single representative of the section Dermoloma is a collection from Tennessee (USA) placed as sister to D. cuneifolium. All other OTUs in our analysis originated from Europe.

Sequencing of 19 available type specimens from Europe and North America (Table 2) and authentic material of ' $D$. simulatum' nom. inval. resulted in 12 successful attempts. Unfortunately, the remaining samples yielded either contaminant or low-quality DNA due to old or poorly preserved specimens. Nine type sequences were represented in our phylogenetic tree (Fig. 2). Based on ex-type sequence position, we identified $D$. cuneifolium, D. alexandri Cons., D. atrocinereum (Pers.) P.D. Orton, D. phaeopodium P.D. Orton and $D$. pusillum Contu. Two collections clustered in our tree with the type of D. hymenocephalum (A.H. Sm.) Singer (Fig. 2), and since they are morphologically similar we considered them as belonging to this species; the low BI support is probably due to short and low quality sequence of the type. Dermoloma emilii-dlouhyi Svrček is synonym of $D$. cuneifolium and $D$. pragensef. obscurum Cons. \& Contu is synonym of $D$. atrocinereum. Ex-type sequence of $D$. hygrophorus also belongs to the genus Dermoloma, but is not represented by a recent collection in our tree. Type sequencing excluded $D$. intermedium var. coniferarum Bon as member of the genus; indeed, a 100\% sequence similarity, based on a Blast search, suggested this taxon corresponds to Pseudolaccaria pachyphylla (Fr.) Vizzini \& Contu.

\section{Morphological observations}

Our field observations were based on material collected by the authors that consisted of 92 specimens of the genus Dermoloma (more than $80 \%$ of all studied samples). Our observations confirmed the previous delimitation of the genus defined by Arnolds (1992): basidiomata with collybioid or tricholomatoid habit; adnate, sinuate or subdecurrent lamellae; farinaceous odor; and a white spore deposit. In addition, we observed only dull colours on basidiomata that combine grey, brown, or white. Microscopic structure of all sequenced collections is always a hymeniderm or pruristratous hymeniderm, and the hyphae always bear clamp connections.

Two North America collections (TENN-F-029387, TENN-F-066899) identified putatively as Dermoloma but placed on a residual branch sister to Pseudotricholoma have similar morphology to Dermoloma. The basidiomata are fleshy and unstaining, lack a veil, resemble in stature $D$. magicum, the pale greyish colouration matches $D$. belerianum, the pileipellis is a hymeniderm, the spores are amyloid, short-ellipsoid, and white in deposit, and clamp connections are present. In addition to this unusual combination of characters, they can be distinguished from Dermoloma by an unpleasant rancid odour even when fresh, although the taste is farinaceous. Macrochemical reactions, viz., $\mathrm{KOH}$ and PDAB, are negative. 
Infrageneric classification of the genus corresponded to two previously recognised groups: species with inamyloid spores are classified here in the subgenus Dermoloma (Fig. 3A) and species with amyloid spores in the subgenus Amylospora (Fig. 3B). These two groups are usually easily distinguishable in the field: the first has pilei usually with mainly grey colour and pale grey to almost white hymenium and stipe. The second group has either brown-grey pilei or darker grey or grey-brown hymenium and stipe.

Representatives of sect. Conica were distinguished from other inamyloid species of the core section by large basidiomata with conical pilei and very pale, almost white lamellae and stipe (Fig. 3D). The single species of sect. Nigrescentia, D. magicum, is distinguished from other species with amyloid spores (classified in sect. Atrobrunnea) by blackening basidiomata (Fig. 3F).

Morphological identification of species was traditionally based on spores. Therefore, we took special attention to spore observations and measured up to 5 collections (depending on material availability) per each OTU defined in our phylogenetic tree (Fig. 2). The majority of OTUs had spores 5-6.5 $\mu \mathrm{m}$ long with ratio of length and width $Q=1.25-1.50$. Members of sect. Dermoloma showed little variability and fell within these ranges. Two OTUs of sect. Conica had narrower spores compared to members of sect. Dermoloma, but showed no spore differences between each other. Dermoloma magicum of sect. Nigrescentia had large spores exceeding $7 \mu \mathrm{m}$ in length. There was only a single OTU of sect. Atrobrunnea with such large spores (D. sp. 10). More distinct differences in both length and shape (Q value) were observed among members of sect. Atrobrunnea. Our spore measurements support the identity of two USA collections clustered with ex-type sequence of $D$. hymenocephalum without a good $\mathrm{BI}$ support in our phylogenetic analysis (Fig. 2), probably due to low type sequence quality. Spores of these two collections are similar to the type and we suggest that all three collections represent a single species.

Some taxa in this study were not identified by a sequence from a type or authentic material but by morphology. Our sequencing of the type species of sect. Atrobrunnea, D. atrobrunneum (Dennis) Bon (described from Trinidad), failed, but our morphological analyses confirmed the pileipellis structure and amyloid spores were typical for $D$. pseudocuneifolium and other members of this group. The conical pilei of $D$. bellerianum and blackening basidiomata of $D$. magicum defined these two species sufficiently. Dermoloma murinellum E. Horak was represented by a single collection from the type locality at high elevation in the Alps, and the spores matched our observations of the type specimen. We assigned the species name $D$. pseudocuneifolium to the largest supported clade of sect. Atrobrunnea that corresponded to a widely adopted concept of the species. Based on pileipellis and spore morphology we confirmed that $D$. fuscobrunneum P.D. Orton, $D$. intermedium Bon and $D$. longibasidiatum Cons., Contu \& Setti belonged to sect. Dermoloma; and D. josserandii Dennis \& P.D. Orton and D. pragense Kubička belong to sect. Atrobrunnea, but their phylogenetic positions were not resolved (and these names were not represented in our tree). Our morphological study excluded $D$. hybridum (Kühner) Bon as a member of the genus Dermoloma because the type has a pileipellis of repent cylindrical hyphae possibly corresponding to the genus Tricholoma Singer.

\section{Taxonomy}


Dermoloma (J. Lange) Singer ex Herink, Sborník Severočeského Musea 1: 62.1958

$\equiv$ Tricholoma stirps Dermoloma J. Lange, Dansk. Bot. Ark. 8(3): 12. 1933

Type: Dermoloma cunneifolium (Fr.) Singer ex Bon

Description: Basidiomata agaricoid with well-developed central pileus and lamellate hymenophore. Pileus up to $75 \mathrm{~mm}$ wide, mainly convex and expanding to plain when mature, with pale or dark colours, combining white, brown and grey tints, sometimes distinctly hygrophanous, translucent-striate or not, surface usually smooth, glabrous, at times cracked when dry. Lamellae adnate to sinuate, at times weakly decurrent, concolourous or paler than pileus. Stipe usually equally long or longer than pileus diameter, up to $15 \mathrm{~mm}$ wide, central, cylindrical, sometimes narrowly fusiform or attenuated near the base, usually coloured like the pileus. Context fragile in pileus, white or pale, odour strongly farinaceous. Pileipellis a hymeniderm, pluristratous hymeniderm or transitional to an epithelium, composed of one, two rarely more layers of inflated, broadly clavate, sphearopedunculate cells. Basidiospores broadly ellipsoid to ellipsoid, usually almost symmetrical, thin-walled, hyaline, white in deposit. Caulocystidia always present. Hyphae with clamp connections, hyphal terminations in pileipellis and stipitipellis with dark brown parietal or sometimes also incrusted pigments.

Dermoloma subgenus Dermoloma

Description: Basidiomata usually with dominating gray tints. Spores inamyloid.

Dermoloma subgenus Amylospora Adamčík, subgenus nova.

Type: Dermoloma phaeopodium P.D. Orton

Diagnosis: Basidiomata usually with dominating brown tints. Spores amyloid.

Dermoloma section Dermoloma

Description: Pileus convex and soon expanding plane. Spores broadly ellipsoid to ellipsoid, $Q<1.5$.

Dermoloma section Conica Adamčík, section nova.

Type: Dermoloma bellerianum Bon

Diagnosis: Pileus conical, when old expanding plane and with distinct umbo. Spores ellipsoid to oblong, Q $>1.5$.

Dermoloma section Atrobrunnea Contu, Boletim da Sociedade Broteriana 65: 80. 1992.

Type: Dermoloma atrobrunneum (Dennis) Bon

Description: Context does not change colour when bruised. 
Dermoloma section Nigrescentia Adamčík, section nova.

Type: Dermoloma magicum Arnolds

Diagnosis: Context turns black when bruised.

\section{Discussion}

Phylogenetic placement of the genus. Our phylogenetic study confirmed that the genus Dermoloma is a member of the Tricholomataceae as resolved by the most recent phylogenetic study that includes the family (Sánchez-García \& Matheny 2016). The latter study placed the genus Pseudotricholoma nested within samples identified as Dermoloma, because of one sample recognised in our study as $\triangle$ Dermoloma

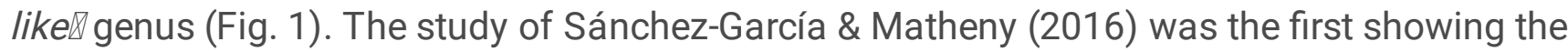
phylogenetic placement of the genus but our study suggested surprisingly high diversity within the genus not expected by any previous study. These results are even more surprising because this genus with at least 23 species in Europe and probably with worldwide distribution has not been included in phylogenetic studies that focused on the Tricholomataceae (Sánchez-García \& Matheny 2016; Hofstetter et al. 2014). Taxonomic identity of the genus Dermoloma in our study is resolved by the placement of the type species $D$. cuneifolium. The phylogenetic placement of Dermoloma inconspicuum in the family Agaricaceae (Kropp 2008) indicates that this species is one of a few that has yet to be combined in other genera, together with $D$. hybridum and $D$. intermedium var. coniferarum, which were excluded from Dermoloma in this study.

Morphological delimitation of the genus and its lower rank taxa. Our study showed clear morphological and phylogenetic circumscription of the genus Dermoloma. Morphologically, it is defined by a combination of farinaceous odour and pluristratous hymeniderm pileipellis of inflated balloon-shaped elements. However, both characters are present also in multiple phylogenetic lineages of the Tricholomataceae and they should not serve as limits to define a group on above-family rank as proposed by Bon (1979), who defined the family Dermolomataceae based on hymeniderm pileipellis structure typical for the genus Dermoloma. Genera included by Bon in this family occurred in different places of the Tricholomataceae tree (Sánchez-García \& Matheny 2016) and very similar pileipellis structure can be observed in very unrelated agarics, for example in the genus Hodophilus (Birkebak et al. 2016).

Taxa excluded in this study have either no distinct smell or have different pileipellis structure. Dermoloma belongs to a group of small brown mushrooms (SBM), the popular term referring to a hyperdiverse morphological fungal group of polyphyletic origin and difficult morphological identification of species. In our experience, Dermoloma can resemble in the field some members of Dennisiomyces,

Pseudoporpoloma, Pseudotricholoma, Tricholoma and possibly also species out of Tricholomataceae. Field identification of Dermoloma should be supplemented with microscopical observations and we recommend paying special attention to spore and pileipellis morphology. 
It is worth to mention inconsistencies about spore amyloidity of some species in the literature. Even the concept of the type species $D$. cuneifolium was inconsistent. Some authors attributed amyloid spores to this species (Josserand 1958, Svrček 1966), but Orton (1980) disagreed with this interpretation and he thought that the species has inamyloid or sometimes weakly amyloid spores. In response, Arnolds (1992) designated a neotype for $D$. cuneifolium with inamyloid spores and Bon (1986) proposed the name $D$. pseudocuneifolium for $D$. cuneifolium in sense of Josserand (1958) (with amyloid spores). The confusions about spore amyloidity have not stopped afterwards. In our study, type specimens of $D$. alexandri and $D$. pragense f. obscurum are placed in the section Dermoloma but original descriptions (Contu et al. 2008) report weakly amyloid spores. This weakly amyloid reaction is observed as a grey hue under certain focus in the light microscope, and it is usually seen in some members of the section Dermoloma. We performed a test placing lamellae fragments of $D$. cuneifolium and $D$. alexandri, reported as having non-amyloid and weakly amyloid spores respectively by Contu et al. (2008), but there was no distinguishable difference in the amyloid reaction. We therefore recognised as amyloid spores only those with strong reaction resulting to dark grey to black tints when spores are accumulated in mass or collapsed.

The species number in the subgenus Dermoloma accepted in the literature (Arnolds 2002, 2003; Contu et al. 2008; Vesterhold 2008, 2012) ranges between three to eight, whilst we recognised 12 species supported by our phylogeny (Fig. 2). Our morphological observations suggest that spore characters used in the literature to distinguish species within the subgenus Dermoloma are usually not reliable, e.g. $D$. cuneifolium, D. alexandri and $D$. atrocinereum have very similar spores (Fig. 2). Future taxonomic studies should include more observations of pileipellis, stipitipellis, lamellae edges, but also more detailed descriptions of macromorphological characters.

Species diversity, distribution and ecology. High number of singletons in our tree and apparent geographic limits of some species suggest that species diversity in Europe might be even higher than 23 recognised OTUs. Based on the sequenced types and morphological characters, we assigned ten species names to the clades in our tree (Fig. 2). We did not studied the type of D. coryleti, but based on the original description (Singer \& Clémençon 1971) it does not have a distinct farinaceous odour and the spores are inamyloid and much larger than any species of the section Dermoloma mentioned in this study. Therefore it is likely that this species is not member of the genus Dermoloma. Concluding from all our abovementioned observations, for the remaining 17 unidentified OTUs in our tree, we have only available five species names that were not assigned to a phylogenetically identified OTU: $D$. fuscobrunneum, $D$. intermedium $D$. josserandii, $D$. longibasidiatum and $D$. pragense. Some of them may represent synonyms. It means that a minimum of 12 species in Europe are so far undescribed. In addition, some species might have not been included in our study. To avoid nomenclatural confusions, description of new European Dermoloma species will require not only type studies but detailed observations of morphological characters combining more characters than are so far used in the nomenclature.

Our study strongly suggests that North America has its authentic Dermoloma diversity different from Europe, because none of the OTUs studied was found in both, Europe and North America. The sampling 
of the genus in our tree seems to be even more insufficient for North America with only 6 recognised OTUs. Five OTUs are members of the section Atrobrunnea together with $D$. hymenocephalum. The single Tennessee (USA) sample in the tree placed in the section Dermoloma is probably the first published record of a species with not amyloid spores in North America. There is an online record of a non-amyloid species identified as D. cuneifolium (http://www.mushroomexpert.com/dermoloma_cuneifolium.html), but this record seems to be misidentified because it has amygdaliform spores that are much narrower than we observed within the genus Dermoloma. This online record is another evidence of insufficient and very rudimental knowledge of the genus in North America.

Ecology of members of Dermoloma is equal to other members of the so-called CHEGD fungi, where this genus is included together with Clavariaceae, Hygrocybe (and other genera of Hygrophoraceae previously placed in this genus), Entoloma, Geoglossaceae (and some species of Leotiaceae previously placed in this family). In Europe, CHEGD fungi are typically found in grassland habitats but in North America they usually grow in forests associated with non-ectomycorrhizal trees (Adamčík et al. 2016; Lodge et al. 2014). It seems that more important than the presence or absence of trees is their affinity to undisturbed sites with a conservation value (Griffith et al. 2013). Their ecology may have a strong link to trophy that is so far unresolved. Analysis of $\mathrm{C}$ and $\mathrm{N}$ isotopes and ${ }^{13} \mathrm{C}$ pulse label experiments and high natural abundance stable isotopes of ${ }^{15} \mathrm{~N}$ and low of ${ }^{13} \mathrm{C}$ in basidiocarps suggest that they form unspecified biotrophic associations with plants (Halbwachs et al. 2018). They have a particular response to available nutrition changes linked to management practices when comparing to other grassland fungi (Caboň et al. in review).

\section{Conclusion}

Our results demonstrated that the real number of species in Europe and North America is higher than expected according to the literature, and the number of OTUs recognised in our phylogeny is much higher than the number of available published Dermoloma names. Before the description of new species, there is an urgent need to fix the morphological concept of already described species and to designate epitypes that will represent species in the phylogeny and provide reference sequences. The morphological arguments and characters used in previous literature must be reconsidered and supplemented by new characters and more precise observations. The high number of OTUs represented by a single sample suggests that the diversity of the genus will be even higher with increasing sampling efforts from Europe, North America, and elsewhere. There are 13 Dermoloma names from other continents, but the only available sequence from outside the USA and Europe corresponds to $D$. inconspicuum from Belize (type of the species is from Venezuela). This suggests that extra-European taxa need urgent revision and sequence data to specify their geographical distributions and morphological and genetic limits.

\section{Declarations}

\section{Ethics approval and consent to participate}




\section{Consent for publication}

Not applicable.

\section{Availability of data and materials}

The sequences generated and/or analysed during the current study are available in the GenBank repository, [https://www.ncbi.nlm.nih.gov/genbank/]. All analysed specimens are deposited in public herbaria indicated in Supplementary table.

\section{Competing interests}

The authors declare that they have no competing interests.

\section{Funding}

The majority of the study has been funded by the Slovak grant VEGA 02/0018/18. The research stay of Munazza Kiran at the Plant Science and Biodiversity Centre of the Slovak Academy of Sciences was funded by the National Scholarship Programme of the Slovak Republic.

\section{Authors' contributions}

SA, MGS and designed the study, the main conceptual ideas and wrote the paper with support from PBM. KA and MGS performed DNA extractions, SA and MGS edited sequences. MGS, MC and SA designed molecular part of the study, performed molecular and phylogenetic analyses. MK, SJ and SA performed morphological measurements. PBM, PAM and AV contributed to the data interpretations. AV, PAM, SA, and SJ and contributed with collecting of European samples and macromorphological descriptions, MGS and PBM provided the study with material and sequences of North American species. PBM provided critical feedback to the study design and paper. All authors revised and approved the final manuscript.

\section{Acknowledgements}

Giovanni Consiglio, Marco Contu, Gareth Griffith, David Harries, Viktor Kučera and all other collectors contributed with their samples or assistance in field are acknowledged. For loaning of type and authentic material we thank curators of herbaria AQUI, E, G, K, LIP, MICH, PRM, UPS and ZT.

\section{References}


Adamčík S, Looney BP, Birkebak JM, Jančovičová S, Adamčíková K, Marhold K, Matheny PB (2016) Circumscription of species of Hodophilus (Clavariaceae, Agaricales) in North America with naphthalene odours. Botany 94:941-956. https://doi.org/10.1139/cjb-2016-0091

Arnolds E (1992) Notulae ad Floram agaricinam neerlandicam - XIX. A revision of Dermoloma (Lange J) Sing. - 1. Persoonia 14(4): 519-532

Arnolds E (1993) Notulae ad Floram agaricinam neerlandicam - XX. A revision of Dermoloma ( Lange J) Sing. - 2. Persoonia 15(2): 187-196

Arnolds E (2002) Dermoloma magicum spec. nov., a grassland fungus mimicking Porpoloma metapodium. Persoonia 17(4): 665-668

Birkebak JM, Adamčík S, Matheny PB (2016) Multilocus phylogenetic reconstruction of the Clavariaceae (Agaricales) reveals polyphyly of the agaricoid members. Mycologia 108: 860-868.

https://doi.org/10.3852/15-370

Bon M (1979) Taxons nouveaux. Documents Mycologiques 9(35): 39-44

Bon M (1986) Novitates - Validations et taxons nouveaux. Documents Mycologiques 17(65): 51-56

Bon M (1998) Novitates - Marasmiaceae et Dermolomataceae comb, st et sp nov. Documents Mycologiques 28(109-110): 6.

Caboň M, Galvánek D, Detheridge AP, Griffith GW, Adamčík S (2020) Mulching has negative impact on fungal and plant diversity in Slovak oligotrophic grasslands. Basic and Applied Ecology, submitted.

Castresana J (2000) Selection of conserved blocks from multiple alignments for their use in phylogenetic analysis. Molecular Biology and Evolution 17: 540-552.

https://doi.org/10.1093/oxfordjournals.molbev.a026334

Contu M, Consiglio G, Setti L (2008) Studi sul genere Dermoloma (Basidiomycota, Tricholomataceae). Micologia e Vegetazione Mediterranea 22(2): 83-118

Gardes M, Bruns TD (1993) ITS primers with enhanced specificity for basidiomycetes - application to the identification of mycorrhizae and rusts. Molecular Ecology 2:113-118. https://doi.org/10.1111/j.1365294X.1993.tb00005.x

Griffith GW, Gamarra JGP, Holden EM, Mitchel D, Graham A, Evans DA, Evans SE, Aron C, Noordeloos ME, Kirk PM, Smith SLN, Woods RG, Hale AD, Easton GL, Ratkowsky DA, Stevens DP, Halbwachs H (2013) The international conservation importance of Welsh 'waxcap' grasslands. Mycosphere 4 (5): 969-984. https://doi.org/10.5943/mycosphere/4/5/10 
Halbwachs H, Easton GL, Bol R, Hobbie EA, Garnett MH, Peršoh D, Dixon L, Ostle N, Karasch P, Griffith GW (2018) Isotopic evidence of biotrophy and unusual nitrogen nutrition in soil dwelling Hygrophoraceae. Environmental Microbiology 20:3573-3588. https://doi.org/10.1111/1462-2920.14327

Hofstetter V, Redhead SA, Kauff F, Moncalvo JM, Matheny PB, Vilgalys R (2014). Taxonomic revision and examination of ecological transitions of the Lyophyllaceae (Basidiomycota, Agaricales) based on a multigene phylogeny. Cryptogamie Mycologie 35:399-425.

https://doi.org/10.7872/crym.v35.iss4.2014.399

Josserand M (1958) Une espèce nouvelle de Tricholomée: Tricholoma (Dermoloma) hygrophorus. Bulletin de la Société mycologique de France 74: 482-491

Katoh K, Standley DM (2013) MA FFT multiple sequence alignment software, version 7: improvements in performance and usability. Molecular Biology and Evolution 30: 772-780.

https://doi.org/10.1093/molbev/mst010

Kearse M, Moir R, Wilson A, Stones-Havas S, Cheung M, Sturrock S, Buxton S, Cooper A, Markowitz S, Duran C, Thierer T, Ashton B, Meintjes P, Drummond A (2012) Geneious Basic: an integrated and extendable desktop software platform for the organization and analysis of sequence data.

Bioinformatics 28:1647-1649. https://doi.org/10.1093/bioinformatics/bts199

Kropp BR (2008) Dermoloma inconspicuum from Belize with molecular support for its placement in the Agaricaceae. Mycotaxon 104: 235-240

Lanfear R, Calcott B, Ho SYW, Guindon S. 2012. Partitionfinder: combined selection of partitioning schemes and substitution models for phylogenetic analyses. Molecular Biology and Evolution 29:16951701. https://doi.org/10.1093/molbev/mss020

Lodge DJ, Padamsee M, Matheny PB, Aime MC, Cantrell SA, Boertmann D, Kovalenko A, Vizzini A, Dentinger BTM, Kirk PM, Ainsworth AM, Moncalvo JM, Vilgalys R, Larsson E, Lücking R, Griffith GW, Smith M E, Norvell LL, Desjardin DE, Redhead SA, Ovrebo CL, Lickey EB, Ercole E, Hughes KW, Courtecuisse R, Young A, Binder M, Minnis AM, Lindner D L, Ortiz-Santana B, Haight J, Læssøe T, Baroni TJ, Geml J, Hattori T (2013) Molecular phylogeny, morphology, pigment chemistry and ecology in Hygrophoraceae (Agaricales). Fungal Diversity 64:1-99. https://doi.org/10.1007/s13225-013-0259-0

Maddison WP, Maddison DR (2019) Mesquite: a modular system for evolutionary analysis. Version 3.61 Available via http://www.mesquiteproject.org

Matheny PB, Liu YJ, Ammirati JF, Hall BD (2002) Using RPB1 sequences to improve phylogenetic inference among mushrooms (Inocybe, Agaricales). American Journal of Botany 89(4):688-698. doi:10.3732/ajb.89.4.688 
Matheny PB (2005) Improving phylogenetic inference of mushrooms with RPB1 and RPB2 nucleotide sequences (Inocybe, Agaricales). Molecular Phylogenetics and Evolution 35:1-20.

doi:10.1016/j.ympev.2004.11.014

Miller MA, Pfeiffer W, Schwartz T (2010) Creating the CIPRES Science Gateway for inference of large phylogenetic trees. New Orleans, LA. Proceedings of the Gateway Computing Environments Workshop (GCE), pp 1-8. https://doi.org/10.1109/GCE.2010.5676129

Orton PD (1980) Notes on British agarics: 7. Notes from the Royal Botanic Garden, Edinburgh 38: 315330

Rambaut A, Suchard MA, Xie D, Drummond AJ (2013) Tracer. Version 1.6. Available via http://beast.bio.ed.ac.uk/software/tracer/

Ronquist F, Teslenko M, Mark P van der, Ayres DL, Darling A, Hohna S, Larget B, Liu L, Suchard MA, Huelsenbeck JP (2012) MrBayes 3.2: efficient Bayesian phylogenetic inference and model choice across a large model space. Systematic Biology 61:539-542. https://doi.org/10.1093/sysbio/sys029

Sánchez-García M, Matheny PB, Palfner G, Lodge DJ (2014) Deconstructing the Tricholomataceae (Agaricales) and introduction of the new genera Albomagister, Corneriella, Pogonoloma and Pseudotricholoma. Taxon 63: 993-1007. https://doi.org/10.12705/635.635.3

Sánchez-García M, Matheny PB (2016) Is the switch to an ectomycorrhizal state an evolutionary key innovation in mushroom-forming fungi? A case study in the Tricholomatineae (Agaricales). Evolution 71(1): 51-65. https://doi.org/10.1111/evo.13099

Singer R (1962) [1961] Type studies on Agarics IV. Sydowia 15(1-6): 133-151

Singer R (1975) The Agaricales in modern taxonomy, 3rd Ed. Cramer, Vaduz.

Singer R (1986) The Agaricales in modern taxonomy, 4th Ed. Koeltz Scientific Books, Koenigstein.

Singer R, Clémençon H (1971) Neue Arten von Agaricales. Schweiz. Z. Pilzk. 49: 118-128

Stamatakis A (2014) RAxML version 8: A tool for phylogenetic analysis and post-analysis of large phylogenies. Bioinformatics 30: 1312-1313. https://doi.org/10.1093/bioinformatics/btu033

Stöver BC, Müller KF (2010) TreeGraph 2: Combining and visualizing evidence from different phylogenetic analyses. BMC Bioinformatics 11: art. no. 7. https://doi.org/10.1186/1471-2105-11-7

Svrček M (1966) Agaricales aus Böhmen. 2. Česká Mycologie 20: 141-150

Vesterholt J (2008) Dermoloma (Lange JE) Singer. In: Knudsen H,. Vesterholt J (eds) Funga Nordica, agaricoid, boletoid and cyphelloid genera, Nordsvamp, Copenhagen. pp 403-405 
Vesterholt J (2012) Dermoloma (J.E. Lange) Singer. In: Knudsen H, Vesterholt J (eds) Funga Nordica, agarioid, boletoid, clavarioid, cyphelloid and gastroid genera. 2nd edition. Nordsvamp, Copenhagen. pp 464-465

Vilgalys R, Hester M (1990) Rapid genetic identification and mapping of enzymatically amplified ribosomal DNA from several Cryptococcus species. Journal of Bateriology 172: 4238-4246. https://doi.org/10.1128/JB.172.8.4238-4246.1990

White TJ, Bruns T, Taylor LS (1990) Amplification and direct sequencing of fungal ribosomal RNA genes for phylogenetics. In: Innis MA, Gelfand DH, Sninsky JJ, White TJ (eds) PCR protocols: a guide to methods and application. Academic Press, Inc, San Diego, pp 322-315. https://doi.org/10.1016/B978-0$12-372180-8.50042-1$

\section{Tables}

Table 1. List of all species and lower rank taxa published or combined in the genus Dermoloma sorted by continent with information of the type country of origin. Names in brackets are invalid.

Africa: 1 name

1. Dermoloma griseocarneum Pegler, Kew Bulletin Additional Series 6: 213 (1977)

Holotypus: Uganda

America: 6 names

2. Dermoloma atrobrunneum (Dennis) Singer ex Bon, Documents Mycologiques 17(65): 51 (1986)

$\equiv$ Tricholoma atrobrunneum Dennis, Transactions of the British Mycological Society 34: 476 (1951)

- Dermoloma atrobrunneum (Dennis) Singer, Sydowia 9(1-6): 375 (1955)

Holotypus: Trinidad and Tobago (Trinidad Isl.)

3. Dermoloma aposcenum Singer, Fieldiana Botany 21: 88 (1989)

Holotypus: Mexico

4. Dermoloma hymenocephalum (A.H. Sm.) Singer, Sydowia 15(1-6): 142 (1962)

三 Collybia hymenocephala A.H. Sm., Papers of the Michigan Academy of Sciences 26: 61 (1941)

$\equiv$ Hydropus hymenocephalus (A.H. Sm.) Redhead, Sydowia 37: 266 (1984)

Holotypus: USA 
5. Dermoloma inconspicuum Dennis, Kew Bulletin 15(1): 78 (1961)

Holotypus: Venezuela

6. Dermoloma pataguae Singer, Fieldiana Botany 21: 89 (1989)

Holotypus: Chile

7. Dermoloma yungense Singer, Beihefte zur Sydowia 7: 61 (1973)

Holotypus: Bolivia

Asia: 4 names

8. Dermoloma cystidiatum Manim. \& Arnolds, Persoonia 17(1): 149 (1998)

Holotypus: India

9. Dermoloma indicum K.N.A. Raj \& Manim., Phytotaxa 177 (4): 239 (2014)

Holotypus: India

10. Dermoloma keralense K.N.A. Raj \& Manim., Phytotaxa 177 (4): 241 (2014)

Holotypus: India

11. Dermoloma scotodes (Berk. \& Broome) Pegler, Kew Bulletin Additional Series 12: 182 (1986)

$\equiv$ Agaricus scotodes Berk. \& Broome, Botanical Journal of the Linnean Society 11(56): 522 (1871)

Holotypus: Sri Lanka

Australia and Oceania: 3 names

12. Porpoloma amyloideum (G. Stev.) E. Horak, New Zealand Journal of Botany 9(3): 407 (1971) 三 Dermoloma amyloideum (G. Stev.) G. Stev., Field Guide to Fungi: 73 (1982)

$\equiv$ Tricholoma amyloideum G. Stev., Kew Bulletin 19(1): 15 (1964)

Holotypus: New Zealand

13. Dermoloma hemisphaericum (G. Stev.) E. Horak, New Zealand Journal of Botany 9(3): 429 (1971)

$\equiv$ Tricholoma hemisphaericum G. Stev., Kew Bull. 19(1): 14 (1964)

Holotypus: New Zealand 
14. Dermoloma murinum (G.M. Taylor \& G. Stev.) E. Horak, New Zealand Journal of Botany 9(3): 438 (1971)

$\equiv$ Tricholoma murinum G.M. Taylor \& G. Stev., Kew Bulletin 19(1): 17 (1964)

Holotypus: New Zealand

Europe: 21 valid names, 4 invalid names

15. Dermoloma alexandri Cons., Micologia e Vegetazione Mediterranea 22(2): 84 (2008)

Holotypus: Italy

16. Dermoloma atrocinereum (Pers.) P.D. Orton, Transactions of the British Mycological Society 43(2): $175(1960)$

三 Agaricus atrocinereus Pers., Synopsis methodica fungorum: 348 (1801)

- Dermoloma atrocinereum (Pers.) Herink, Sb. severočeského Musea, Historia Naturalis 1: 62 (1958)

Neotypus designated by Contu, Consiglio \& Segtti (2008): Italy

17. Dermoloma bellerianum Bon, Documents Mycologiques 28(nos 109-110): 6 (1998)

Holotypus: France

18. [Dermoloma cheilocystidiatum Contu, Bollettino dell'Associazione Micologica ed Ecologica Romana 15(no. 48): 4 (2000), nom. inval. published as nomen provisorium]

Authentic material: Italy.

19. Dermoloma coryleti Singer \& Clémençon, Schweizerische Zeitschrift für Pilzkunde 49(9): 120 (1971)

Holotypus: Czech Republic

20. Dermoloma cuneifolium (Fr.: Fr.) Bon, Documents Mycologiques 17(65): 51. 1986.

- Agaricus cuneifolius Fr., Observationes mycologicae 2: 99 (1818)

Neotypus designated by Arnolds (1992): Sweden

21. Dermoloma cuneifolium var. punctipes Arnolds, Persoonia 14(4): 529 (1992)

Holotypus: The Netherlands

22. Dermoloma emiliae-dlouhyi Svrček, Česká Mykologie 20(3): 147 (1966) 
Holotypus: Czech Republic

23. Dermoloma fuscobrunneum P.D. Orton, Notes from the Royal Botanical Garden Edinburgh 38(2): 326 (1980)

Holotypus: United Kingdom

24. [Dermoloma glauconitens (Fr.) Bon, Documents Mycologiques 17(65): 51. (1986) nom. illegit. (superfluum)]

三 Agaricus glauconitens Fr., Syst. Mycol. 3: 22. 1832.

- Agaricus nitens Batsch, Elenchus fungorum. Continuatio secunda: 21. 1789: Fr., Syst. Mycol. 1: 116. 1821.

25. Dermoloma hybridum (Kühner) Bon, Bulletin Annual de la Fédération Centre-Est d'Histoire Naturelle et de Mycologie 1: 14 (1979)

$\equiv$ Tricholoma hybridum Kühner, Ann. Sci. Franche-Comté 2: 31 (1947)

Holotypus: France

26. Dermoloma hygrophorus Joss., Bull. Soc. Linn. Lyon 39(1): 6 (1970)

三 Tricholoma hygrophorus Joss., Bulletin de la Société Mycologique de France 74(4): 482 (1958)

Holotypus: France

27. Dermoloma intermedium Bon, Documents Mycologiques 9(35): 42 (1979)

Holotypus: France

28. Dermoloma intermedium var. coniferarum Bon, Documents Mycologiques 17(65): 51 (1986)

Holotypus: France

29. Dermoloma josserandii Dennis \& P.D. Orton, Transactions of the British Mycological Society 43(2): $226(1960)$

Holotypus: United Kingdom

30. Dermoloma longibasidiatum Cons., Contu \& Setti, Micologia e Vegetazione Mediterranea 22(2): 110 (2008)

Holotypus: Italy

31. Dermoloma magicum Arnolds, Persoonia 17(4): 665 (2002)

Page 21/28 
Holotypus: The Netherlands

32. Dermoloma murinellum E. Horak, Sydowia 39: 110 (1987)

Holotypus: Switzerland

33. [Dermoloma nitens Fr. ex Raithelh., Metrodiana 8(2-3): 52 (1979), nom. inval. ]

34. Dermoloma phaeopodium P.D. Orton, Notes from the Royal Botanical Garden Edinburgh 28(2): 327 (1980)

三 Dermoloma josserandii var. phaeopodium (P.D. Orton) Arnolds, Persoonia 15(2): 195 (1993)

Holotypus: United Kingdom

35. Dermoloma pragense Kubička, Česká Mykologie 29(1): 31 (1975)

$\equiv$ Dermoloma pseudocuneifolium var. pragense (Kubička) Bon, Documents Mycologiques 17(65): 52 (1986)

Holotypus: Czech Republic

36. Dermoloma pragense f. obscurum Cons. \& Contu, Micologia e Vegetazione Mediterranea 22(2): 99 (2008)

Holotypus: Italy

37. Dermoloma pseudocuneifolium Herink ex Bon, Documents Mycologiques 17(65): 52 (1986)

Holotypus: France

38. Dermoloma pusillum Contu, Micologia e Vegetazione Mediterranea 22(2): 105 (2008)

Holotypus: Italy

39. [Dermoloma simulatum Cons., Contu \& Setti, in Contu, Consiglio \& Setti, Micologia e Vegetazione Mediterranea 22(2): 110. 2008, nom. inval. described as 'ad int.']

Authentic material: Italy

Table 2. List of European and North American type and authentic herbarium material and sequencing results. HT - holotype, NT - neotype, AM - authentic material, GB - will be replaced by a Genbank number. 


\begin{tabular}{|c|c|c|c|c|}
\hline species & collection details & Herbarium & $\begin{array}{l}\text { type } \\
\text { status }\end{array}$ & $\begin{array}{l}\text { sequencing } \\
\text { outputs }\end{array}$ \\
\hline D. alexandri Cons. & $\begin{array}{l}\text { ITALY. Mesole (FE), Boscone della } \\
\text { Mesola, G. Consiglio, M. Panchetti, R. } \\
\text { Bolletta \& C. Orlandini, 12. Sep } 2004\end{array}$ & $\begin{array}{l}\text { herbarium of } \\
\text { G. Consiglio } \\
\text { (GC04317) }\end{array}$ & HT & GB \\
\hline $\begin{array}{l}\text { D. atrocinereum } \\
\text { (Pers.) P.D. Orton }\end{array}$ & $\begin{array}{l}\text { ITALY. Villeta Barrea (AQ), Abruzzo, } \\
\text { M. Contu et al., 19. Sep } 2003\end{array}$ & $\begin{array}{l}\text { AQUI (Contu } \\
\text { 19.IX.2003) }\end{array}$ & NT & GB \\
\hline D. bellerianum Bon & FRANCE. Beller, 30. Sep 1972 & $\begin{array}{l}\text { LIP (Bon } \\
912)\end{array}$ & HT & not located \\
\hline $\begin{array}{l}\text { D. coryleti Singer \& } \\
\text { Clémençon }\end{array}$ & $\begin{array}{l}\text { CZECHIA. Kroměříš, R. Singer, } 30 . \\
\text { Sep } 1970\end{array}$ & $\begin{array}{l}F \text { (R. Singer } \\
\text { C-5230) }\end{array}$ & $\mathrm{HT}$ & $\begin{array}{l}\text { not } \\
\text { accessed }\end{array}$ \\
\hline $\begin{array}{l}\text { D. cuneifolium (Fr.: } \\
\text { Fr.) Bon }\end{array}$ & $\begin{array}{l}\text { SWEDEN. Småland, Femsjö, } \\
\text { 'Avaberget', S. Lundell \& G. Haglund, } \\
\text { 19. Sep } 1948\end{array}$ & $\begin{array}{l}\text { UPS F- } \\
631065\end{array}$ & NT & GB \\
\hline $\begin{array}{l}\text { D. cuneifolium var. } \\
\text { punctipes Arnolds }\end{array}$ & $\begin{array}{l}\text { NETHERLANDS. prov. Limburg, } \\
\text { Wijlre, 'Wrakelberg', E. Arnolds, } 22 \text {. } \\
\text { Oct } 1984\end{array}$ & L 0821553 & HT & GB \\
\hline $\begin{array}{l}\text { D. emiliae-dlouhyi } \\
\text { Svrček }\end{array}$ & $\begin{array}{l}\text { CZECHIA. Brdské hřebeny Mts., } \\
\text { Vižina, M. Svrček, 20. Sep } 1965\end{array}$ & PR 610931 & $\mathrm{HT}$ & failed \\
\hline $\begin{array}{l}\text { D. fuscobrunneum } \\
\text { P.D. Orton }\end{array}$ & $\begin{array}{l}\text { UK. Somerset, Bickham Wood, } \\
\text { Crawley, P.D. Orton, 24. Oct } 1975\end{array}$ & E 16876 & HT & failed \\
\hline $\begin{array}{l}\text { D. hybridum } \\
\text { (Kühner) Bon }\end{array}$ & $\begin{array}{l}\text { FRANCE. bois d'Avoudrey (près } \\
\text { Besançon), R. Kühner, 16. Oct } 1946\end{array}$ & G 126676 & HT & failed \\
\hline $\begin{array}{l}\text { D. hygrophorus } \\
\text { Joss. }\end{array}$ & $\begin{array}{l}\text { FRANCE. Ain, Quincieux, Lacombe \& } \\
\text { Josserand, 14. Aug } 1956\end{array}$ & G 260855 & HT & $\begin{array}{l}\text { GB, partial } \\
\text { ITS } \\
\text { sequence }\end{array}$ \\
\hline $\begin{array}{l}\text { D. } \\
\text { hymenocephalum } \\
\text { (A.H.Sm.) Singer }\end{array}$ & $\begin{array}{l}\text { USA. Michigan, Dexter, Silver lake, } \\
\text { A.H. Smith, 23. Sep } 1938\end{array}$ & MICH 10228 & HT & $\begin{array}{l}\text { GB, partial } \\
\text { ITS } \\
\text { sequence }\end{array}$ \\
\hline $\begin{array}{l}\text { D. intermedium } \\
\text { Bon }\end{array}$ & $\begin{array}{l}\text { FRANCE. Somme, Warlus, towards } \\
\text { Airaines, M. Bon, Oct. } 1967\end{array}$ & $\begin{array}{l}\text { LIP (Bon } \\
71081)\end{array}$ & $\mathrm{HT}$ & failed \\
\hline $\begin{array}{l}\text { D. intermedium var. } \\
\text { coniferarum Bon }\end{array}$ & $\begin{array}{l}\text { FRANCE. Argol, Mornard, 28. Oct } \\
1982\end{array}$ & $\begin{array}{l}\text { LIP (Bon } \\
8116)\end{array}$ & $\mathrm{HT}$ & $\begin{array}{l}\text { GB, not } \\
\text { Dermoloma }\end{array}$ \\
\hline $\begin{array}{l}\text { D. josserandii } \\
\text { Dennis \& P.D. Orton }\end{array}$ & $\begin{array}{l}\text { UK. South Somerset, Spaxton, } \\
\text { Hawkridge, E. Marrigae, 15. Sep } 1958\end{array}$ & $K(M) 37580$ & $\mathrm{HT}$ & failed \\
\hline $\begin{array}{l}\text { D. longibasidiatum } \\
\text { Cons., Contu \& } \\
\text { Setti }\end{array}$ & $\begin{array}{l}\text { ITALY. Pergine (TN), Susà, G. } \\
\text { Consiglio, G. Marasca et B. Oss-Emer, } \\
\text { 30. Nov 1993, }\end{array}$ & $\begin{array}{l}\text { herbarium of } \\
\text { G. Consiglio } \\
\text { (GC93318) }\end{array}$ & $\mathrm{HT}$ & failed \\
\hline $\begin{array}{l}\text { D. magicum } \\
\text { Arnolds }\end{array}$ & $\begin{array}{l}\text { NETHERLANDS. Limburg, Epen, } \\
\text { Cotessen, E. Arnolds, 21. Oct } 1995\end{array}$ & $\begin{array}{l}\mathrm{L} \text { (Arnolds } \\
6701)\end{array}$ & $\mathrm{HT}$ & not located \\
\hline
\end{tabular}




\begin{tabular}{|c|c|c|c|c|}
\hline species & collection details & Herbarium & $\begin{array}{l}\text { type } \\
\text { status }\end{array}$ & $\begin{array}{l}\text { sequencing } \\
\text { outputs }\end{array}$ \\
\hline $\begin{array}{l}\text { D. murinellum } \mathrm{E} . \\
\text { Horak }\end{array}$ & $\begin{array}{l}\text { SWITZERLAND. Graubünden, N des } \\
\text { Albulpasses (Terrassas), E. Horak, } \\
\text { 30. Aug } 1982\end{array}$ & $\begin{array}{l}\text { ZT Myc } \\
42786 \\
\text { (Horak } \\
\text { ZT1573) }\end{array}$ & $\mathrm{HT}$ & failed \\
\hline $\begin{array}{l}\text { D. phaeopodium } \\
\text { P.D. Orton }\end{array}$ & $\begin{array}{l}\text { UK. Devon, Membury, P.D. Orton, } 28 . \\
\text { Oct } 1977\end{array}$ & E 16877 & HT & GB \\
\hline $\begin{array}{l}\text { D. pragense } \\
\text { Kubička }\end{array}$ & $\begin{array}{l}\text { CZECHIA. Praha, „Kinského sady“, E. } \\
\text { Wichanský } 22 \text {. Jun } 1965\end{array}$ & PR 611173 & $\mathrm{HT}$ & failed \\
\hline $\begin{array}{l}\text { D. pragensef. } \\
\text { obscurum Cons. \& } \\
\text { Contu }\end{array}$ & $\begin{array}{l}\text { ITALY. Monte Grino, near Piobbico } \\
\text { (PU), G. Consiglio \& M. Maletti, } 22 \text {. } \\
\text { Oct } 2006\end{array}$ & $\begin{array}{l}\text { herbarium of } \\
\text { G. Consiglio } \\
\text { (GC06186) }\end{array}$ & HT & GB \\
\hline $\begin{array}{l}\text { D. } \\
\text { pseudocuneifolium } \\
\text { Herink ex Bon }\end{array}$ & $\begin{array}{l}\text { FRANCE. near Saint-Valery-sur- } \\
\text { Somme, Oct } 1968\end{array}$ & $\begin{array}{l}\text { LIP (Bon } \\
81006)\end{array}$ & HT & failed \\
\hline D. pusillum Contu & $\begin{array}{l}\text { ITALY. Sardinia, Olbia (OT), } \\
\text { Pittolongu, M. Contu, 30. Dec } 2006\end{array}$ & $\begin{array}{l}\text { AQUI (Contu } \\
\text { 30.XII.2006) }\end{array}$ & HT & GB \\
\hline $\begin{array}{l}\text { D. simulatum } \\
\text { Cons., Contu \& } \\
\text { Setti, nom. inval. }\end{array}$ & $\begin{array}{l}\text { ITALY. Trento-Alto Adige, Susà (TN), } \\
\text { G. Consiglio, G. Marasca \& B. Oss- } \\
\text { Emer, 30. Oct } 1993\end{array}$ & $\begin{array}{l}\text { herbarium of } \\
\text { G. Consiglio } \\
\text { (GC02284) }\end{array}$ & AM & failed \\
\hline
\end{tabular}

\section{Figures}




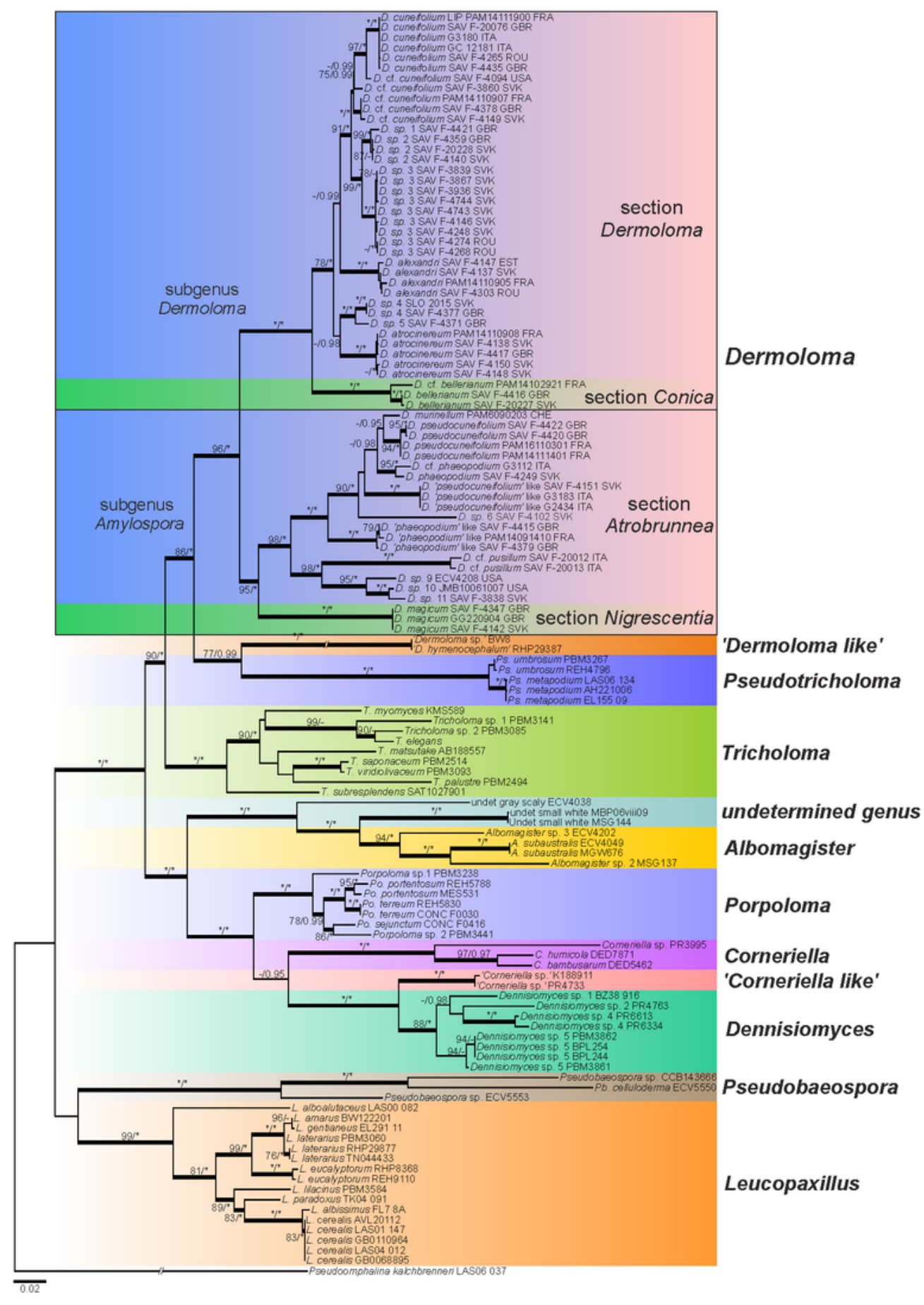

\section{Figure 1}

Maximum likelihood (RAxML) phylogeny of Tricholomataceae inferred from nrlTS, nrLSU, rpb1 and rpb2 loci. Maximum likelihood bootstrap support values greater than 70 and Bayesian posterior probabilities greater or equal to 0.95 are indicated at nodes. Bold lines represent branches supported by both $\mathrm{ML}$ and BI. Asterisks indicate $\mathrm{ML}=100$ or $\mathrm{Bl}=1.00$. 


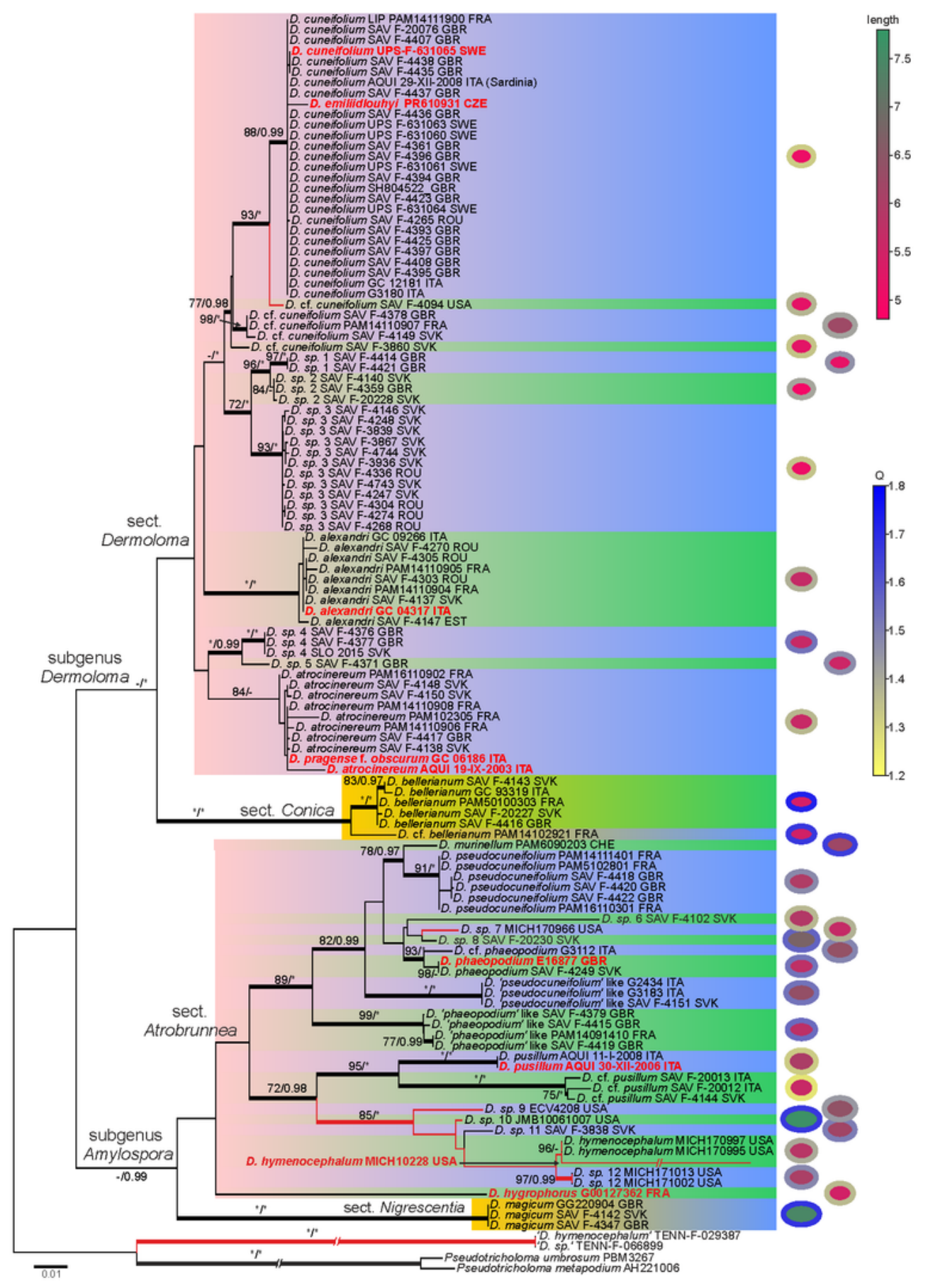

\section{Figure 2}

Maximum likelihood (RAxML) phylogeny of the genus Dermoloma inferred from nrlTS, nrLSU, rpb1 and rpb2 DNA loci. Maximum likelihood bootstrap support values greater than 70 and Bayesian posterior probabilities greater or equal to 0.95 are indicated at nodes. Bold lines represent branches supported by both $\mathrm{ML}$ and $\mathrm{Bl}$. Asterisks indicate $\mathrm{ML}=100$ or $\mathrm{Bl}=1.00$. Type specimens are indicated in red. American lineages are labelled in red and European ones in black. Spore pictures at the nodes show amyloid 
reaction typical for each subgenus. Pictures of basidiomata show typical members of the sections, sect. Dermoloma is represented by D. cuneifolium, sect. Conica by D. bellerianum, sect. Atrobrunnea by D. pseudocuneifolium and sect. Nigrescentia by D. magicum. Diagrams to the right represent spores, the size is proportional to the spore average calculated from the spore measurements from all the collections of the recognised lineages. The colours inside the ellipses correspond to spore length and the colours of the outline correspond to the spore length/width ratio $(\mathrm{Q})$. Colour scales are shown to the right.

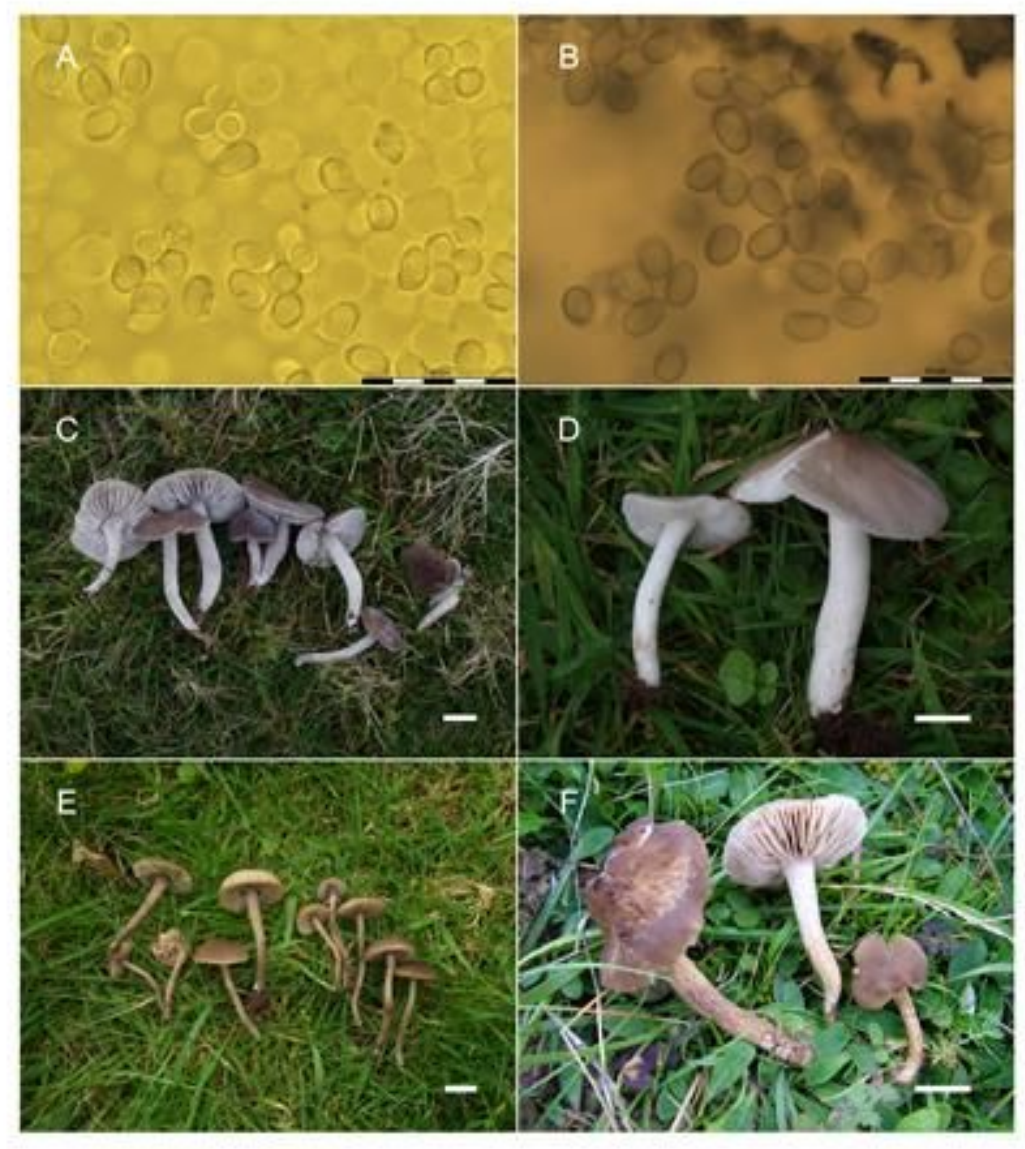

\section{Figure 3}

Examples of Dermoloma morphology. A. Inamyloid spores of subgenus Dermoloma (D. cuneifolium, SAV F-4423). B. Amyloid spores of subgenus Amylospora (D. pseudocuneifolium, SAV F-4422). C. Basidiomata of section Dermoloma (D. cuneifolium, SAV F-4436). D. Basidiomata of section Conica (D. 
bellerianum, SAV F-4416). E. Basidiomata of section Atrobrunnea (D. pseudocuneifolium, SAV F-4420). F. Basidiomata of section Nigrescentia (D. magicum, SAV F-4242). Scale of represents $10 \mathrm{~mm}$ for basidiomata.

\section{Supplementary Files}

This is a list of supplementary files associated with this preprint. Click to download.

- supplementaryTableS1.docx

- supplementaryTables1.docx 